\title{
A Neutralization Test for Trachoma and Inclusion Blennorrhoea Viruses Grown in HeLa Cell Cultures
}

\author{
By P. REEVE AND DORIS M. GRAHAM \\ Medical Research Council Trachoma Research Unit, The Lister Institute of \\ Preventive Medicine, Chelsea Bridge Road, London, S.W. 1
}

(Received 16 June 1961)

\section{SUMMARY}

A neutralization test for the viruses of trachoma and inclusion blennorrhoea grown in HeLa cell cultures is described. Antiserum titres, which are independent of virus concentration over a wide range, can be accurately and reproducibly estimated. Limited cross-neutralization tests indicate a close antigenic relationship between one strain of trachoma virus and two strains of inclusion blennorrhoea.

\section{INTRODUCTION}

Since the isolation of trachoma virus by T'ang, Chang, Huang \& Wang (1957) similar agents have been isolated from patients with trachoma and inclusion blennorrhoea in at least thirteen countries. There are few serological tests for the exploration of these agents. In addition to its use as an index of immune response, a neutralization test might have important applications in the study of strain differences. An accurate titration method in cell culture (Furness, Graham \& Reeve, 1960) now permits quantitative studies of neutralization in vitro. The present paper describes a neutralization test for trachoma and inclusion blennorrhoea viruses grown in cell culture.

\section{METHODS}

Cell cultures. HeLa cells were grown in $250 \mathrm{ml}$. Pyrex feeding bottles containing $10 \mathrm{ml}$. medium, and for virus titrations, in Leighton tubes containing coverslips and $2 \mathrm{ml}$. medium. The medium consisted of Hank's saline solution containing $5 \%(v / v)$ calf serum, $10 \%(v / v)$ human serum, and $0.5 \%(w / v)$ lactalbumin hydrolysate, adjusted to $\mathrm{pH} 7 \cdot 2-7 \cdot 4$ with $1 \cdot 4 \%(\mathrm{w} / \mathrm{v}) \mathrm{NaHCO}_{3}$.

Viruses. The TE 55 strain of trachoma virus (T'ang et al. 1957), the LB 1 strain of inclusion blennorrhoea (Jones, Collier \& Smith, 1959) and LB 4 strain of inclusion blennorrhoea (Jones \& Collier, unpublished) were used.

Virus suspensions. For immunization infected chick embryo yolk sacs were homogenized with sucrose + potassium glutamate (SPG) solution (Bovarnik, Miller \& Snyder, 1950) to give a $20 \%, \mathrm{w} / \mathrm{v}$, suspension. After low-speed centrifugation the virus was deposited in a high-speed angle centrifuge at $4^{\circ}$ and resuspended in SPG solution to two-fifths of the original volume. The infective titre of the suspensions was about $10^{5}$ egg infectious doses $/ \mathrm{ml}$. (EID 50/ml.). The suspensions were stored at $-70^{\circ}$.

HeLa cell-grown virus suspensions were prepared from infected monolayers of 
HeLa cells grown in Pyrex feeding bottles. Three days after inoculation the cells from each bottle were suspended in $10 \mathrm{ml}$. medium and disrupted with an MSE Mullard ultrasonic disintegrator with a power output of $60 \mathrm{~W}$. at $20 \mathrm{kc}$. $/ \mathrm{sec}$. The virus was deposited in the high-speed angle centrifuge at $4^{\circ}$ and resuspended in $1 \mathrm{ml}$. SPG solution.

For titration, infected HeLa cells from each Pyrex bottle were suspended in $10 \mathrm{ml}$. medium, disrupted as above, and diluted in medium. Cell-cultured virus was used immediately after preparation.

Antisera. Rabbits were immunized by weekly intravenous injections of live virus, receiving either six $1 \mathrm{ml}$. injections of yolk-sac-cultured virus or twelve $1 \mathrm{ml}$. injections of cell-cultured virus. They were bled 2 weeks after the final injection; the sera were stored at $-20^{\circ}$. Sera were heated at $56^{\circ}$ for $30 \mathrm{~min}$. before use.

Neutralization test. A high concentration of serum was required to prevent heat inactivation of the virus. Accordingly, twofold dilutions of antiserum were made in normal rabbit serum and $0.5 \mathrm{ml}$. amounts were mixed with equal volumes of virus suspension. After incubation at $37^{\circ}$ for $\mathbf{3 0} \mathrm{min}$., four Leighton tubes were each inoculated with $0.2 \mathrm{ml}$. of each serum + virus mixture to assess the number of inclusion forming units (IFU; Furness et al. 1960). Control tubes were inoculated with virus that had been incubated with normal rabbit serum or antiserum against normal yolk sac. The degree of neutralization was determined by comparing the number of IFU/ml. in the antiserum + virus mixtures with that of the controls.

\section{RESULTS}

\section{Neutralization with undiluted antisera}

Undiluted serum neutralized $90-100 \%$ of virus when tested against concentrations ranging from $3.7 \times 10^{7}$ to $3.2 \times 10^{4} \mathrm{IFU} / \mathrm{ml}$. (Table 1). This result suggests that neutralization was independent of virus concentration in the presence of excess antibody. Although the antiserum titres were low, neutralization appeared to be specific, since similar dilutions of control serum did not inhibit virus growth.

\section{Neutralization with diluted antiserum}

Figure 1 shows the neutralization of $\mathrm{LB1}$ virus with sera prepared against both egg- and HeLa-cell-cultured antigens. Each point represents the mean of the infected cell counts in 4 replicate tubes inoculated with a given virus + serum mixture. Antiserum R197, prepared against LB1 virus cultured in HeLa cells, was titrated on four occasions against concentrations of virus ranging from $6.7 \times 10^{4}$ to $8.4 \times 10^{5} \mathrm{IFU} / \mathrm{ml}$. The results of serum dilutions $1 / 32$ and $1 / 64$ are incomplete since some tubes were lost because of bacterial contamination. Antiserum R 261, prepared against egg-cultured LB1 virus, was similarly titrated on two occasions; the infective titres of the virus suspensions were, respectively, $3.0 \times 10^{5}$ and $8.2 \times$ $10^{4} \mathrm{IFU} / \mathrm{ml}$.

With serum dilutions which neutralized less than $75 \%$ of virus, inhibition was directly proportional to serum dilution (Fig. 1). It is therefore convenient to express neutralization titres in terms of a $50 \%$ end-point: since the virus assay has a standard error of $\pm 10 \%$ (Furness et al. 1960), a $50 \%$ decrease of virus titre is highly significant. Repeat titrations of both sera gave similar end-points; a 1/32 


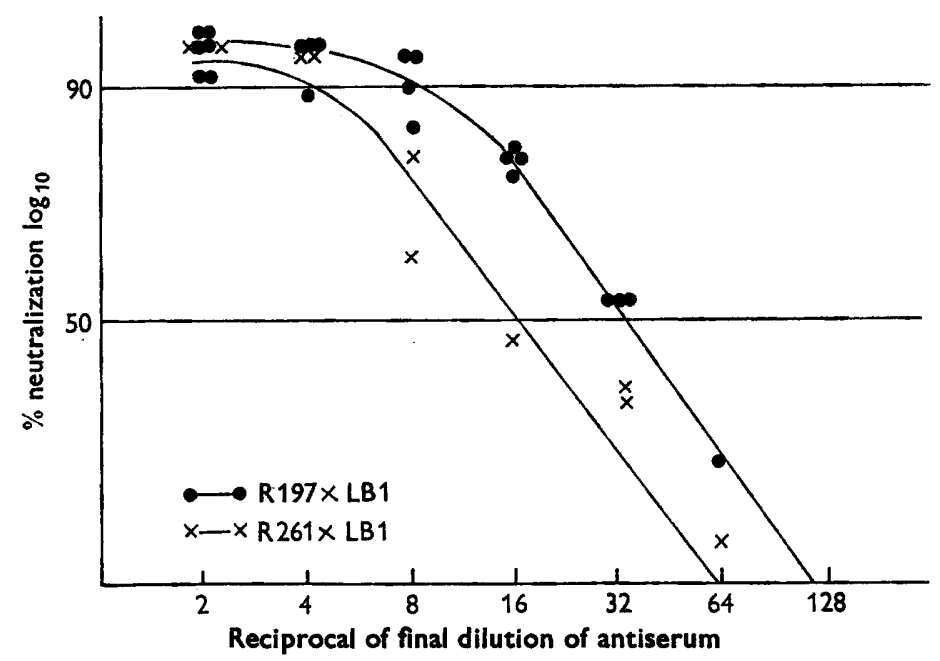

Fig. 1. Titration of 2 anti-LB 1 rabbit sera against homologous virus. Each point is the mean of four replicates. Serum R197 (black dots) was titrated on four occasions. Serum $\mathbf{R} 261$ was titrated on two occasions.

dilution of antiserum $\mathbf{R} 197$ neutralized $50 \%$ of virus over a 12-fold range and a $1 / 16$ dilution of antiserum $R 261$ over a 10 -fold range of virus concentration.

Cross-neutralization. Experiments with single antiserum dilutions showed that the LB 1 and the LB4 strains of inclusion blennorrhoea were neutralized by an antiserum prepared against the TE 55 strain of trachoma virus (Table 1).

Table 1. Neutralization of trachoma and inclusion blennorrhoea viruses in

\section{HeLa cell cultures}

\begin{tabular}{|c|c|c|c|c|c|}
\hline $\begin{array}{c}\text { Rabbit } \\
\text { antiserum }\end{array}$ & $\begin{array}{l}\text { Final } \\
\text { dilution }\end{array}$ & $\begin{array}{c}\text { Strain } \\
\text { of virus } \\
\text { neutralized }\end{array}$ & $\begin{array}{c}\text { Before } \\
\text { neutralization }\end{array}$ & $\underset{\text { neutralization }}{\text { After }}$ & $\begin{array}{c}\text { Degree of } \\
\text { neutralization } \\
(\%)\end{array}$ \\
\hline R143 anti-TE55 & $1 / 2$ & $\begin{array}{l}\text { TE55 } \\
\text { TE55 } \\
\text { TE 55 }\end{array}$ & $\begin{array}{l}3.7 \times 10^{7} \\
3 \cdot 7 \times 10^{6} \\
8 \cdot 4 \times 10^{5}\end{array}$ & $\begin{array}{r}2.6 \times 10^{8} \\
+<7.0 \times 10^{8} \\
<7.0 \times 10^{8}\end{array}$ & $\begin{array}{r}98 \\
>99 \\
>99\end{array}$ \\
\hline R261 anti-LB1 & $1 / 2$ & $\begin{array}{l}\text { LB1 } \\
\text { LB1 } \\
\text { LB1 }\end{array}$ & $\begin{array}{l}3.7 \times 10^{6} \\
3 \cdot 4 \times 10^{4} \\
3 \cdot 2 \times 10^{4}\end{array}$ & $\begin{array}{r}<7.0 \times 10^{8} \\
<7.0 \times 10^{8} \\
4.4 \times 10^{8}\end{array}$ & $\begin{array}{r}>98 \\
>80 \\
88\end{array}$ \\
\hline R197 anti-LB 1 & $\mathbf{1} / \mathbf{2}$ & $\begin{array}{l}\text { LB 1 } \\
\text { LB1 } \\
\text { LB1 } \\
\text { LB 1 } \\
\text { LB } 1\end{array}$ & $\begin{array}{l}8.4 \times 10^{5} \\
8.0 \times 10^{5} \\
7.4 \times 10^{5} \\
6.7 \times 10^{4} \\
5.0 \times 10^{4}\end{array}$ & $\begin{array}{r}1.2 \times 10^{4} \\
3.0 \times 10^{4} \\
<7.0 \times 10^{8} \\
<7.0 \times 10^{3} \\
<7.0 \times 10^{8}\end{array}$ & $\begin{array}{r}98 \\
96 \\
>\quad 99 \\
>\quad 90 \\
>\quad 86\end{array}$ \\
\hline R 143 anti-TE 55 & $\begin{array}{l}1 / 2 \\
1 / 10 \\
1 / 8 \\
1 / 8\end{array}$ & $\begin{array}{l}\text { LB1 } \\
\text { TE55 } \\
\text { LB4 } \\
\text { LB4 }\end{array}$ & $\begin{array}{l}8.7 \times 10^{5} \\
8.4 \times 10^{5} \\
1.5 \times 10^{5} \\
9.4 \times 10^{4}\end{array}$ & $\begin{array}{r}<7.0 \times 10^{8} \\
4.0 \times 10^{5} \\
5.9 \times 10^{4} \\
3.7 \times 10^{4}\end{array}$ & $\begin{array}{r}>98 \\
62 \\
60 \\
60\end{array}$ \\
\hline
\end{tabular}

* Virus suspension containing less than $7 \cdot 0 \times 10^{3} \mathrm{IFU} / \mathrm{ml}$. cannot be assayed by the technique used. 


\section{DISCUSSION}

Bell, Snyder \& Murray (1959) showed that immunization protected mice against the toxic effects of an intravenous dose of live trachoma virus. This test revealed at least two antigenically distinct strains of trachoma virus from Saudi Arabia and Egypt. This test can, however, be applied only to strains that are toxic for mice; furthermore, the toxic effect cannot be neutralized in vitro. Bernkopf (1959) found that some strains of trachoma virus induced specific pulmonary lesions in mice when instilled intranasally, their capacity to do this being neutralized by preliminary incubation with serum from immunized rabbits.

The present paper describes the first in vitro neutralization test for the viruses of trachoma and inclusion blennorrhoea grown in cell culture, by which antiserum titres can be accurately estimated. In previously described neutralization tests with these and other viruses of the psittacosis-lymphogranuloma group, virus is titrated against a constant dilution of antiserum (see review by Wenner, 1958). It is not practicable to use a constant amount of virus in these tests because so far it has proved impossible to store cell-cultured viruses without loss of infectivity. Nevertheless, the $50 \%$ neutralization end-point is independent of virus concentration over a wide range, and the yield from a $250 \mathrm{ml}$. bottle culture 2 or 3 days after inoculation is sufficient for a neutralization test, without a determination of its exact titre. Antiserum titres at this degree of neutralization are sufficiently high to permit cross-absorption tests. Limited cross-neutralization tests indicate a close antigenic relationship between a Chinese strain of trachoma and two London strains of inclusion blennorrhoea.

We wish to thank Miss Elizabeth Fraser for supplying HeLa cell cultures and Mr R. Arnold for technical assistance.

\section{REFERENCES}

Bell, S. D., SNyder, J. C. \& Murray, E. S. (1959). Immunization of mice against toxic doses of homologous elementary bodies of trachoma. Science, 130, 626.

Bernkopf, H. (1959). The susceptibility of white mice to a strain of trachoma virus and their use in neutralization tests. Bull. Res. Council Israel, 8 E, 25.

Bovarnik, M. R., Miller, J. C. \& SNyder, J. C. (1950). The influence of certain salts, amino acids, sugars and proteins on the stability of rickettsiae. J. Bact. 59, 509.

Furness, G., Graham, D. M. \& ReEve, P. (1960). The titration of trachoma and inclusion blennorrhoea viruses in cell culture. J. gen. Microbiol. 23, 613.

Jones, B. R., Collier, L. H. \& SmITH, C. H. (1959). Isolation of virus from inclusion blennorrhoea. Lancet, i, 902.

T'ang, F. F., Chang, H. L., Huang, Y. T. \& Wang, K. C. (1957). Studies on the etiology of trachoma with special reference to isolation of the virus in chick embryo. Chinese Med. J. 75, 429.

Wenner, H. A. (1958). Psittacosis-Lymphogranuloma group of viruses. Advanc. Virus Res. 5, 39. 